Kong. Res. J. 1(1) : 50-53, 2014

Kongunadu Arts and Science College, Coimbatore

\title{
EVALUATION OF ANTIBACTERIAL POTENTIAL OF THE TRADITIONAL MEDICINAL CLIMBER, SOLENA AMPLEXICAULIS (LAM.) GANDHI. (CUCURBITACEAE)
}

\author{
Karthika, K*., S. Paulsamy and S. Jamuna \\ Department of Botany, Kongunadu Arts and Science College, Coimbatore - 641029. \\ *E.mail: karthika1431989@gmail.com
}

\begin{abstract}
Solena amplexicaulis (Cucurbitaceae) is a traditional medicinal climber generally prescribed for wound healing by the local healers in western districts of Tamil Nadu. The aim of the present study was focused on investigating the potential of antibacterial activity via in vitro approach. The aqueous and organic solvent extracts (hexane, benzene, chloroform and methanol) of the stem part of S. amplexicaulis were tested against 15 human pathogenic bacteria by agar well diffusion method. Results showed promising antibacterial activity against the bacteria tested. Among them, chloroform and benzene extracts were found to have more potent inhibitory effect in comparison to the other extracts. It proves the therapeutic importance of the species in curing infectious diseases and encouraged for its extensive use in health care practices.
\end{abstract}

Key words: Solena amplexicaulis, antibacterial activity, agar well diffusion method.

\section{INTRODUCTION}

Phytomedicines play a major role in human health care system and a source of great economic value all over the world (Ahmad et al., 1998). These medicinal plants represent a rich source of antimicrobial agents, used medicinally in different countries and as a source of many potent and powerful drugs (Uniyal et al., 2006). These beneficial medicinal effects of plant materials typically result from the combinations of secondary products present in the plant (i.e.) alkaloids, steroids, tannins, phenolics, flavonoids etc which are capable of producing definite physiological action on body (Bishnu et al., 2009). As per the World Health Organization (WHO) reports, $80 \%$ of the world populations are presently using herbal medicine for some aspects of primary health care. Many pharmaceutical companies are also showing interest in manufacturing plant derived drug based on their belief of 'Green Medicine' is safe and more dependable than the costly synthetic drugs, which have adverse side effects (Sujatha, 2005).

Solena amplexicaulis (Cucurbitaceae) is a perennial dioeceous climber with tuberous root found throughout Asia mainly in hilly dry deciduous forests and scrub jungles. It has been used in traditional Indian medicine for various ailments like spermatorrhoea, thermogenic, appetizer, cardiotonic, diuretic and haemorrhoids (Kritchevsky, 1978) and its leaves have good anti-inflammatory activity and also recommended for skin lesions and other skin diseases (Arun et al., 2011). The leaf juice is taken orally to cure jaundice (Mohammed et al.,
2011). The fresh stem is externally used to promote the conception (Ignacimuthu et al., 2008). Unripe fruits are eaten raw to strengthen the body (Jeyaprakash et al., 2011) and used as vegetable also. It helps to increase the secretion of milk during lactation and also used as expectorant, antidepressant and antianxiety and to reduce asthmatic conditions. (Bandyopadhyay and Sobhan $\mathrm{Kr}$ Mukherjee, 2009). Root is a stimulant and purgative (http://hpforest.nic.in/potter.htm). The decoction of the root is taken orally to cure stomachache (Abdolbaset et al., 2011). The whole plant is determined to be a potential source of natural antioxidant activity (Venkateshwarlu et al., 2011 and Karthika et al., 2012) and also used for the treatment of diabetes (Pullaiah et al., 2003).

Considering the indigenous uses of this species, the present investigation was taken up with an objective to evaluate the antibacterial potential of stem extract against certain human pathogenic bacteria that may provide scientific justification to the traditional uses in treating various ailments.

\section{MATERIALS AND METHODS}

\subsection{Plant material}

The stem of S. amplexicaulis was collected from Madukkarai, Coimbatore district, Tamil Nadu. Collected plant materials were washed thoroughly in tap water, shade dried and then homogenized to fine powder and stored in air tight bottles. 


\subsection{Preparation of extracts}

About 50g coarsely powdered plant material $(50 \mathrm{~g} / 250 \mathrm{ml})$ was extracted in the soxhelt extractor for 8 to 10 hours, sequentially with hexane, benzene, chloroform, methanol and water. Then each extract was evaporated to dryness.

\subsection{Bacterial strains}

In vitro antibacterial activity was examined for the crude extracts of stem of the study plant, against 15 bacterial species which include the Gram positive strains viz., Streptococcus faecalis, $S$. pyogenes, Bacillus subtilis, B. thuringiensis, Staphylococcus aureus and Enterococcus faecalis and Gram negative strains viz., Klebsiella pneumoniae, Salmonella paratyphi, S. paratyphi A, S. paratyphi B, Escherichia coli, Proteus vulgaris, P. mirabilis, Serratia marcescens and Pseudomonas aeruginosa.

All these bacterial strains were obtained from the Department of Microbiology, Tamil Nadu Agricultural University, Coimbatore. All the bacteria were maintained at $4^{\circ} \mathrm{C}$ on nutrient agar slants for further use.

\subsection{Bacterial susceptibility testing}

An inoculum of each of the pathogenic bacterial strains was suspended in $5 \mathrm{ml}$ of nutrient broth and incubated at $37^{\circ} \mathrm{C}$ for $18 \mathrm{hrs}\left(10^{6}-10^{8}\right.$ bacteria $\mathrm{CFUml}^{-1}$ ). Bioassay was carried out by using agar well diffusion method (Perez et al., 1990; Murray et al., 1995; Olurinola, 1996). Inoculum was spread over Muller - Hinton agar medium with sterile glass spreader. A well of $6 \mathrm{~mm}$ diameter was made using a sterile cork borer and filled with $50 \mu \mathrm{l}$ of different extracts by using micropipette in each well in aseptic condition. The plates were kept at room temperature for absorption of extract in the medium and further incubated in an incubator at $37^{\circ} \mathrm{C}$ for $24 \mathrm{hrs}$. The antibacterial activity was evaluated by measuring the diameter of inhibition zone $(\mathrm{mm})$. Ampicillin was used as positive control $(50 \mu \mathrm{l} / \mathrm{ml})$ and DMSO (Dimethyl sulphoxide) as negative control $(50 \mu \mathrm{l})$.

\subsection{Statistical analysis}

All the analyses were done in triplicate and results were expressed as mean \pm SD. The data were subjected to one way analysis of variance (ANOVA) and the significance of the difference between mean was determined by Duncan's Multiple Range Test with significance level, $\mathrm{P}<0.05$. ANOVA was performed using the statistical software SPSS (SPSS Inc. Chicago, USA).

\section{RESULTS AND DISCUSSION}

Agar well diffusion method is widely used in in vitro method of evaluation of antimicrobial activity of various chemicals. The size of the inhibition zone depends on the solubility of the test material, time and temperature of incubation (Weiss et al., 1996). In the present study the antibacterial activity of aqueous and solvent extracts (hexane, benzene, chloroform and methanol) of stem part of $S$. amplexicaulis against certain human pathogenic bacterial which include both gram positive and gram negative in terms of inhibition ability were presented in Table - 1. Among the five extracts, benzene and chloroform extracts showed broad spectrum of antibacterial activity in comparison to hexane and methanol extracts which showed mild activity with the zone of inhibition diameter ranged from $8-24 \mathrm{~mm}$ and $6-12 \mathrm{~mm}$, respectively. The water extract showed almost no activity. Different solvents have been reported to have different capacity to extract phytoconstituents according to their solubility or polarity, and most of the compounds are dissolved well in alcoholic solvents than in water (Marjorie, 1999). The antibacterial activity was compared with the inhibitory activity of antibiotic, Ampicillin which showed varied inhibitory zones of $13-24 \mathrm{~mm}$. The negative control DMSO, which showed no zone of inhibition. Among the 15 bacteria, Staphylococcus aureus of Gram positive type showed higher susceptibility to stem extract than the antibiotic, ampicillin. S. aureus is a well known wound pathogen (Lullmann et al., 2000) which can be found as the part of the normal skin flora and in the nasal passages (Kluytmans et al., 1997 and Cole et al., 2001). In the study, Gram positive bacteria are little bit sensitive than that of Gram negative bacteria because the latter are frequently reported to have developed multidurg resistance due to their outer membrane which act as a barrier to many environmental substances, including antibiotics (Tortora et al., 2001; Johansson et al., 2011; Johnson et al., 2011; Ramakant et al., 2011). The zone of inhibition $\geq 9-15 \mathrm{~mm}$ is an indication of strong antimicrobial activity (Rani and Khullar, 2004). So, the stem extract of $S$. amplexicaulis having the potential for killing the bacteria. High antibacterial effects of alcoholic extracts of certain Cucurbitaceae members were already reported well Trichosanthes cucumerine (Arawwawala et al., 2011), Citrullus colocynthis (Gurudeeban et al., 2010) and Coccinia grandis (Farrukh et al., 2008)). 


\section{CONCLUSION}

The present research is a right step to the direction of searching novel and more effective antibacterial compounds in plants. In conclusion the species, $S$ amplexicaulis extracts exhibited antibacterial activity against both Gram positive and Gram negative bacterial strains mediating the presence of a broad spectrum of antibacterial compounds. This study suggests that further research will be needed for pharmacological aspects and elucidate the specific phytoactive compounds in the stem extract of $S$. amplexicaulis and hence to go for commercial application through pharmaceutical industries.

\section{ACKNOWLEDGEMENT}

The authors are gratefully acknowledging University Grants Commission, New Delhi for financial assistance to carryout this work.

\section{REFERENCES}

Abdolbaset, G., L.Gerhard, F. Liu and S. Joachim, (2011). Ethnobotanical study of medicinal plants utilised by Hani ethnicity in Naban River Watershed National Nature Reserve, Yunnan, China. Journal of Ethnopharmacology 134(3): 651-667.

Ahmad L., Z. Mohammed, and F. Mohammed, (1998). Screening of some Indian medicinal plants for their antimicrobial properties. Journal of Ethnopharmacology 62: 183-193.

Arawwawala, L.D.A.M., M.I. Thabraw, L.S.R. Arambewela, N. Fernando and L.D. Guruge, (2011). Antibacterial activity of Trichosanthes cucumerina Linn. extracts. International Journal of Pharmaceutical and Biological Archives 2(2): 808-812.

Arun Ch., R. Satheesh Kumar, S. Srinu, G. Lal Babu, G. Raghavendra Kumar and J. Amos Babu, (2011). Anti inflammatory activity of aqueous extract of Leaves of Solena amplexicaulis, International Journal of Research in Pharmaceutical and Biomedical Science 2(4):1617-1619.

Bandyopadhyay, S. and Kr. Sobhan Mukherjee. (2009). Wild edible plants of Koch Bihar district, West Bengal, Natural product Radiance 8(1): 64-72.

Bishnu, J., Sunil L. and Anuja S. (2009). Antibacterial property of different medicinal plants: Ocimum sanctum, Cinnamomum zeylanicum, Xanthoxylum armatum and Origanum maorane. Kathmandu University, Journal of Science, Engineering and Technology 5: 143-150.

Cole, A.M., S. Tahk, A. Oren, D. Yoshioka, Y.H. Kim, A. Park and T. Ganz, (2001). Determinants of
Staphylococcus aureus nasal carriage. Clinical and Diagnostic Laboratory Immunology 8(6): 1064-9.

Farrukh, U., H. Shareef, S. Mahmud, S.A. Ali and G.H. Rizwani (2008), Antibacterial activity of Coccinia grandis L. Pakistan Journal of Botany 40(3): 1259-1262.

Gurudeeban, S., E. Rajamanickam, T. Ramanathan and K. Satyavani, (2010). Antimicrobial activity of Citrullus colocynthis in gulf of mannar. International Journal of Current Research 2: 078-081.

http://hpforest.nic.in/potter.htm

Ignacimuthu, S., M. Ayyanar and K. Sankarasivaraman, (2008). Ethanobotanical study of medicinal plants used by Paliyar tribals in Theni district of Tamil Nadu, India. Fitoterapia 79: 562-568.

Jeyaprakash, K., M. Ayyanar, K.N. Geetha and T. Sekar, (2011). Traditional uses of medicinal plants among the tribal people in Theni District (Western Ghats), Southern India. Asian Pacific Journal of Tropical Biomedicine S20-S25.

Johansson, M., D.M. Phuong, S.M. Walther and H. Hanburger, (2011). Need for improved antimicrobial and infection control stewardship in Vietnamese intensive care units. Tropical Medicine and International Health 16(6): 737743.

Johnson, M., E.G. Wesely, M.S. Kavitha and V.Uma, (2011). Antibacterial activity of leaves and inter-nodal callus extracts of Mentha arvensis L. Asian pacific Journal of Tropical Medicine 4(3), 196-200.

Karthika, K., S. Paulsamy and S. Jamuna, (2012). Evaluation of in vitro antioxidant potential of methanolic leaf and stem extracts of Solena amplexicaulis (Lam.) Gandhi. Journal of Chemical and Pharmaceutical Research 4(6): 3254-3258.

Kluytmans, J., A. Van Belkum and H. Verbrugh, (1997). Nasal carriage of Staphylococcus aureus: epidemiology, underlying mechanisms, and associated risks. Clinical Microbiology Reviews 10 (3): 505-520.

Kritchevsky, D. (1978). Fiber, lipids and atherosclerosis. American Journal of Clinical Nutrition 31: S65-S74.

Marjorie, M.C. (1999). Plant product as antimicrobial agents. Clinical Microbiology reviews. 12: 564582.

Mohammed, R., C. Paritosh, P. Alok Kumar, N. Dilruba, A. Rasheda, J. Farhana, F. Dilara, A. Mira, N. Nusratun, A. Shamima, and J. Rownak, 
(2011). A survey of preventive medicinal plants used by the Chakma residents of Hatimara (south) village of Rangamati district, Bangladesh. American-Eurasian Journal of Sustainable Agriculture 5(1): 92-96

Murray, P.R., E.J. Baron, M.A. Pfaller, F.C. Tenover and H.R. Yolken, (1995). Manual of Clinical Microbiology, $6^{\text {th }}$ Ed. ASM Press, Washington, DC. 15-18.

Olurinola, P.F. (1996). A laboratory manual of pharmaceutical microbiology. Idu, Abuja, Nigeria 69-105.

Perez C., M. Paul and P.Bazerque, (1990). An antibiotic assay by the agar well diffusion method. Acta Biologiae Et Medicinae Experimentails 15: 113-115.

Pullaiah, T., K.S.R. Murthy, P.S.P. Goud, T.D.C. Kumar and R. Vijayakumar (2003). Medicinal plants used by the tribals of Nallamalais, Eastern Ghats of India. Journal of Tropical Medicinal Plants 4(2): 237-244.

Ramakan, P., A.K. Verma, R. Misra, K.N. Prasad, G. Chand, A. Mishra, G. Agarwal, A. Agarwal and S.K. Mishra, (2011). Changing microbiological profile of pathogenic bacteria in Diabetic food infections: time for a rethink on which empirical therapy to choose? Diabetologia 54(1): 58-64.

Sujatha, S. (2005). Complementary and alternative therapies in palliative care: A transition from modern medicine to traditional medicine in India. Journal of Cancer Pain and Symptom Palliation 1: 9-25.

Tortora, GJ., Funke BR. and Case CL. (2001). Microbiology: an Introduction, Benjamin Cummings, San Francisco.88.

Uniyal, S.K., K.N. Singh, P. Jamwal and B. Lal, (2006). Traditional use of medicinal plants among the tribal communities of Chhota Bhangal, Western Himalaya. Journal of Ethnobiology and Ethnomedicine 2: 1-14.

Venkateshwarlu, E., A. Raghuram Reddy., P. Goverdhan, K. Swapna Rani and G. Jayapal Reddy, (2011). In vitro and In vivo antioxidant activity of methanolic extract of Solena amplexicaulis (Whole plant). International Journal of Pharmacy and Biological Science, 1(4): 522-533.

Weiss, E.I., M. Shalhav and Z. Fuss, (1996). Assessment of antibacterial activity of endodontic sealers by a direct contact test. Endodontics and Dental Traumatology, 12: 176184.

Table 1: In vitro antibacterial activity of stem extract of Solena amplexicaulis by agar well diff method.

\begin{tabular}{|c|c|c|c|c|c|c|c|}
\hline \multirow{2}{*}{ S.No } & \multirow{2}{*}{ Name of the bacteria } & \multicolumn{6}{|c|}{ Diameter of inhibition zone (mm) } \\
\hline & & Control* & Hexane & Benzene & Chloroform & Methanol & Water \\
\hline & Gram positive & & & & & & \\
\hline 1. & Streptococcus faecalis & $24.33 \pm 0.15^{\mathrm{a}}$ & - & $11.33 \pm 0.93^{b}$ & $12.33 \pm 0.52^{\mathrm{b}}$ & $9.00 \pm 0.10^{c}$ & - \\
\hline 2. & S. pyogenes & $20.00 \pm 0.81^{\mathrm{a}}$ & $6.67 \pm 0.53^{b}$ & $11.33 \pm 0.16^{c}$ & $13.67 \pm 0.23^{\mathrm{ac}}$ & $8.33 \pm 0.51^{\mathrm{bc}}$ & - \\
\hline 3. & Bacillus subtilis & $23.33 \pm 0.21^{\mathrm{a}}$ & $6.67 \pm 0.58^{\mathrm{b}}$ & $14.33 \pm 0.63^{\mathrm{c}}$ & $16.33 \pm 0.72^{\mathrm{c}}$ & $8.33 \pm 0.89^{b}$ & $6.82 \pm 0.29^{b}$ \\
\hline 4. & B. thuringiensis & $18.33 \pm 0.58^{\mathrm{a}}$ & $8.00 \pm 0.65^{b}$ & $8.00 \pm 0.20^{\mathrm{b}}$ & $12.67 \pm 0.44^{\mathrm{c}}$ & $7.67 \pm 0.53^{\mathrm{b}}$ & - \\
\hline 5. & Staphylococcus aureus & $19.67 \pm 0.53^{\mathrm{a}}$ & $11.33 \pm 0.21^{\mathrm{b}}$ & $24.33 \pm 0.59 c$ & $23.67 \pm 0.15^{c}$ & $11.33 \pm 0.08^{b}$ & - \\
\hline \multirow[t]{2}{*}{6.} & Enterococcus faecalis & $20.00 \pm 0.65^{a}$ & $6.33 \pm 0.31^{\mathrm{b}}$ & $13.33 \pm 0.16^{c}$ & $18.00 \pm 0.36^{\mathrm{ac}}$ & $10.00 \pm 0.30^{\mathrm{bc}}$ & - \\
\hline & Gram negative & & & & & & \\
\hline 5. & Klebsiella pneumonia & $15.00 \pm 0.10^{\mathrm{a}}$ & - & $13.00 \pm 0.81^{\mathrm{a}}$ & $15.61 \pm 0.81^{\mathrm{a}}$ & $7.67 \pm 0.79^{b}$ & - \\
\hline 6. & Salmonella paratyphi & $23.00 \pm 0.73^{\mathrm{a}}$ & - & $9.67 \pm 0.53^{b}$ & $11.33 \pm 0.57 \mathrm{c}$ & $8.00 \pm 0.26^{b}$ & $7.67 \pm 0.62^{b}$ \\
\hline 7. & Salmonella paratyphi A & $16.00 \pm 0.20^{\mathrm{a}}$ & $6.67 \pm 0.28^{b}$ & $11.00 \pm 0.10^{c}$ & $13.67 \pm 0.58^{\mathrm{c}}$ & $7.33 \pm 0.11^{\mathrm{b}}$ & - \\
\hline 8. & S. paratyphi B & $13.33 \pm 0.58^{\mathrm{a}}$ & $8.33 \pm 0.15^{b}$ & $13.33 \pm 0.15^{\mathrm{a}}$ & $17.00 \pm 0.20^{c}$ & $10.00 \pm 0.20^{\mathrm{ab}}$ & - \\
\hline 9. & Escherichia coli & $16.33 \pm 0.23^{\mathrm{a}}$ & $8.00 \pm 0.65^{b}$ & $13.67 \pm 0.36^{c}$ & $16.00 \pm 0.61^{\mathrm{a}}$ & $9.00 \pm 0.10^{\mathrm{b}}$ & - \\
\hline 10. & Proteus vulgaris & $19.00 \pm 0.73^{a}$ & $8.33 \pm 0.28^{b}$ & $16.67 \pm 0.51^{\mathrm{c}}$ & $17.67 \pm 0.64^{\mathrm{ac}}$ & $12.33 \pm 0.41^{\mathrm{bc}}$ & - \\
\hline 11. & P. mirabilis & $19.00 \pm 0.36^{\mathrm{a}}$ & $6.50 \pm 0.35^{b}$ & $12.33 \pm 0.44^{\mathrm{c}}$ & $13.67 \pm 0.53^{c}$ & $7.67 \pm 0.53^{b}$ & - \\
\hline 12. & Serratia marcescens & $18.00 \pm 0.20^{\mathrm{a}}$ & $7.67 \pm 0.31^{b}$ & $18.00 \pm 0.20^{\mathrm{a}}$ & $17.00 \pm 0.30^{\mathrm{a}}$ & $9.33 \pm 0.58^{c}$ & - \\
\hline 13. & Pseudomonas aeruginosa & $16.67 \pm 0.89^{a}$ & $7.67 \pm 0.52^{b}$ & $10.00 \pm 0.65^{c}$ & $14.67 \pm 0.31^{\mathrm{ac}}$ & $9.67 \pm 0.15^{\mathrm{bc}}$ & - \\
\hline
\end{tabular}

